\title{
Vloga protokola v Republiki Sloveniji
}

UDK: $341.7 / .8(497.4)$

\author{
Zlata Jakše \\ Ministrstvo za zunanje zadeve \\ zlata.jakse@gov.si
}

\section{IZVLEČEK}

Glavni namen v tem članku je prikazati delovanje protokola, upoštevanje protokolarnih pravil, ki izhajajo iz zgodovinskih tradicij in običajev, načel mednarodnega prava in diplomatske prakse. Strnjeno so prikazane naloge protokola, načela in predpisi mednarodnega prava. Upoštevanje protokolarnih pravil je bistveni del mednarodnih dogodkov. Brez njih je državniški posel nepojmljiv tako na notranjem kot tudi na mednarodnem področju. Protokol se spreminja in prilagaja sodobnim načinom obnašanja, zato se bodo protokolarna pravila sčasoma dopolnjevala z novimi spoznanji, ki se bodo uveljavila doma in $v$ svetu.

Ključne besede: protokol, diplomacija, ceremonial, protokol kot služba.

\section{Uvod}

Protokol je prav poseben pojem $v$ mednarodnih in tudi v medčloveških odnosih. Zajema vsa pravila obnašanja $v$ najrazličnejših situacijah in ob najrazličnejših priložnostih: od osnovnih pravil bontona, ki veljajo $v$ vsakodnevnem zasebnem življenju do kompleksnih pravil ali celo mednarodno sprejetih standardov, ki urejajo odnose med državami oz. njihovimi predstavniki. Vsaka organizacija mora za svoj uspeh in preprečevanje popolnega kaosa upoštevati določena pravila. Potrebno je, da se meddržavni odnosi odvijajo po splošno sprejetih pravilih in navadah ter neki obliki predvidene organizacije.

Pravila in zakone, ki veljajo v posamezni družbi, je treba upoštevati, saj je to nujno za normalne odnose med ljudmi.

Upoštevanje protokolarnih pravil je torej bistveni del mednarodnih dogodkov. Brez njih je državniški posel nepojmljiv tako na notranjem kot tudi na mednarodnem področju. Namen protokolarnih pravil je poenostavitev diplomatskega 


\section{Zlata Jakša}

\section{Vloga protokola v Republiki Sloveniji}

življenja, za kar skrbi protokol kot služba za izvajanje dela zunanje politike, kjer se odvijajo najbolj ključni dogodki predsednika republike, predsednika vlade, ministra za zunanje zadeve in drugih ministrov.

Protokol je tesno povezan s položajem posameznika, tako da je sprejet kot pripada njegovi funkciji in dostojanstvu. Ker pomaga ustvariti prijetno vzdušje in ustrezno situacijsko klimo, predpostavljamo, da lahko pomembno vpliva na pričakovane rezultate. Protokol, še posebej tisti del, ki se nanaša na ceremonial, lahko vidno odraža raven odnosov med državama.

Protokol mora biti neviden in ne sme se ga čutiti, njegova pomembnost pa se oceni takrat, ko postane viden, torej ko $v$ praksi ni ustrezno izvajan in nastanejo problemi. Poznavanje protokolarnih zakonitosti in protokolarne prakse ter kompleksne mednarodne komunikacije in s tem povezane spretnosti diplomatskih veščin $\vee$ različnih družbah, sistemih in šolah protokola so vredni posebne pozornosti.

Protokol je okvir, skozi katerega se lahko država dejavnikom v mednarodni skupnosti predstavlja in profilira svojo kulturno in državno istovetnost. Ta potencialno promocijska funkcija protokola je še posebej pomembna za manjše države, ki imajo $v$ mednarodnih odnosih praviloma manjšo prepoznavnost.

Protokol in ugled sta imela nekdaj še večji pomen, kot ga imata danes. Zato se je kmalu pojavilo vprašanje urejenih pravil preseansa'. V zgodovini diplomatskega prava je ugled predstavnikov držav, ki so ga razumeli kot ugled države oziroma suverene predstavljane države, prvi zahteval mednarodnopravno urejanje. $V$ mnogih državah so protokolarna opravila osredotočena v enem samem uradu, ki opravlja protokolarne storitve ne samo za potrebe ministrstva za zunanje zadeve, temveč za vlado $v$ celoti, za predsednika vlade in za šefa države, predsednika parlamenta in druge visoke funkcionarje kot npr. predsednika vrhovnega ali ustavnega sodišča.

Protokol danes ni samo to, kar lahko opazujejo državljani neposredno (ali posredno prek množičnih medijev). Vsaka država ima službo protokola, ki skrbi za to, da vsako diplomatsko in konzularno predstavništvo mednarodnih organizacij

1 Preseans je $v$ diplomatski terminologiji prednostni vrstni red. Preteklost pozna mnogo različnih pojmovanj prednosti. Naj navedem le nekatere; Vattel (Genet I., 1931, str. 298) pravi, da je sama narava ustvarila čudovito enakopravnost pravic med suverenimi narodi. Neka velika in močna država je bolj vplivna $\vee$ univerzalni družbi kot neka manjša država, zato je razumno, da ji ceremonial poda prvo mesto med enakimi. Danes so vse države enakopravne in morajo biti kot take obravnavane $\vee$ mednarodni skupnosti in so $v$ pogledu prednosti enako upoštevane. Ustanovna listina OZN (1945: 2. člen, točka 1) je uveljavila načelo "suverene enakosti vseh držav« in to načelo velja tudi glede prednosti. Zato danes na mnogih mednarodnih konferencah z žrebom določijo črko abecede, od katere se potem začne razvrščati sedeže držav ali določati red predsedovanja konferenci. 
dobi ustrezne privilegije po mednarodnih pravnih normah in običajih ter skrbi, da lahko nemoteno posluje (Čačinović, 1994, str. 76).

\section{Opredelitev temeljnih pojmov protokolarne službe}

\subsection{Ceremonial}

Ceremonial so predpisi, ki določajo pravila lepega vedenja tako $v$ uradnem kot $\vee$ zasebnem življenju, $\vee$ katerega so vpletene različne države ter njihovi predstavniki na mednarodni ravni. Ceremonial pomeni "obredje, tj. celotnost kakih obredov," hkrati je tudi "obrednik, pravila ali predpisi za opravljanje obredov« (Slovar tujk, 2002).

Ceremonial "je vpeljal red $\vee$ neizogibno neurejenem svetu« (Hamilton, Langhorne, 1995, str. 70). Wood in Serres (1971, str. 17) pravita, da ni družbe brez hierarhije in da ni civilizacije brez ceremoniala. Ceremonial je priznan sistem mednarodne vljudnosti (Guzelj, 1994, str. 6).

Naloga ceremoniala je ustvariti take pogoje in ozračje, ki omogočajo razvoj miroljubnih odnosov med suverenimi državami, kot tudi vzpostavljanje bilateralnih odnosov. Ceremonial nima predpisanih mednarodnih norm, ampak ga v vsaki državi predpiše njen poglavar ali vlada, pri čemer upošteva mednarodno prakso.

Ceremonial je lahko bolj ali manj slovesen, vedno pa odraža raven odnosov med državami ter zaželenega napredka, poglobitev in napredovanje začetega sodelovanja. S kompleksnostjo ceremoniala gostitelj tudi izkazuje stopnjo pomembnosti držav oziroma njihovih predstavnikov, ki jih gosti (Hamilton, Langhorne, 1995, str. 70). Čeprav naj bi posamezna država enako obravnavala vse druge države oziroma njihove predstavnike.

Ceremonial je le ena od številnih, čeprav najpomembnejših vsebin protokola. Izraz protokol se nanaša na proceduralna pravila diplomacije, od katerih nekatera, ne vsa, zajemajo ceremonial (Berridge, 2002, str. 107).

\subsection{Protokol}

Protokolarna pravila Državnega zbora Republike Slovenije opredeljujejo protokol kot »urad oziroma posebno službo pri vladi in/ali ministrstvu za zunanje zadeve, ki skrbi za stike s tujimi diplomatskimi misijami, organizira obiske 


\section{Zlata Jakša}

\section{Vloga protokola v Republiki Sloveniji}

državnih delegacij, pripravlja sprejeme in druge pogostitve ter organizira državne svečanosti«.

Protokol je zbirka pravil in predpisov, ki v protokolu veljajo kot zakoni. Pri vsakem dogodku se praviloma pojavijo izredne in nepredvidljive okoliščine, ki od protokolarne službe zahtevajo hitro, pravilno in učinkovito odločanje in ukrepanje, kar daje tej službi pri delu določeno svobodo in inovativnost. Ob delu se protokolarna služba tako tudi stalno razvija in izpolnjuje posamezne elemente protokola, ki jih dopolnjuje z navadami drugih dežel. Protokol je stroka, ki mora delovati brezhibno in neodvisno od dnevne politike, naloge morajo biti opravljene brez zastoja in diskretno. Za vsak protokol velja, da je dober, kadar je »neviden«, a ves čas prisoten. Protokolarna pravila so temeljna določila za ceremoniale, ki jih morajo udeleženci upoštevati pri protokolarnih dogodkih. Cilj teh pravil je, da se zaščiti dostojanstvo in ugled vsake države, kakor tudi njenih najvišjih državnih in diplomatskih predstavnikov (Osolnik, 1998, str. 141).

Ksenija Benedetti, šefinja Protokola RS, pravi, da "protokol predstavljajo splošno sprejeta in dolgo uveljavljena načela obnašanja v meddržavnih in mednarodnih odnosih, ki so se izkazala kot potrebna in koristna, pri čemer gre za uveljavljanje načel kurtuazije ${ }^{\mathbf{2}}$ in spoštovanja dostojanstva, katerih cilj je zaščiten ugled vsake države in njenih najvišjih državnih predstavnikov«.

Protokol je svojevrsten mednarodni sporazum, zbirka pisanih in običajnih norm medsebojnega obnašanja držav in njihovih predstavnikov, kot tudi posebna ustanova ali več takih, ki se ukvarjajo z uporabo takih norm. Protokol imajo nekateri za bonton diplomacije, zaradi tega nekateri celo za »najodličnejšo in najsubtilnejšo diplomacijo» (Mikolić, 2002, str. 11). Pravila protokola so bila podobno kot imunitete in načelo nevmešavanja $v$ mednarodno pravo in običaje uvedena predvsem za omogočanje komunikacije med državami (Holsti, 1995, str. 134).

Za vse protokolarne elemente velja strogo načelo, da jih je treba uporabljati enako za vse primerljive priložnosti. Pri obravnavanju predstavnikov tujih držav je na prvem mestu pravil protokola načelo enakosti. $\vee$ okviru danih pravil $\checkmark$ protokolu vendarle obstaja nekaj svobode. Dejstvo je namreč, da protokol ni in tudi ne sme biti tog, kot bi se zdelo zaradi potrebne formalnosti pri državniških dogodkih, temveč se elementi protokola nenehno razvijajo, dopolnjujejo in prilagajajo spremembam v družbi.

2 «Vljudno, ljubeznivo vedenje« (Verbinc, 1974, str. 395). 
„Vsaka država $\vee$ okviru mednarodnih običajev in prakse povsem samostojna odloča o tem, kako bo uveljavljala protokolarne norme, vendar mora te norme, ko jih sprejme, uveljavljati dosledno in na enak način do vseh svojih tujih gostov enakega ranga» (Benedetti, 2003, str. 54).

\section{Organizacija protokola v Republiki Sloveniji}

\subsection{Naloge Protokola RS}

»Protokol RS opravlja protokolarne zadeve za predsednika RS, predsednika DZ RS, predsednika Vlade RS, poleg tega pa tudi za predsednika Državnega sveta RS, predsednika Ustavnega sodišča, varuha človekovih pravic, predsednika Računskega sodišča in za ministra za zunanje zadeve«.

»Protokol RS opravlja strokovno in organizacijsko delo ter ob obiskih osebnosti oziroma delegacij tujih držav in ob obiskih osebnosti iz RS v tujini zagotovi tolmače. Ob soglasju generalnega sekretarja Vlade RS opravlja protokolarne zadeve tudi za druge organe, kadar so ti nosilci protokolarnih dogodkov državnega pomena«.

Protokolarni dogodki, ki jih pripravlja in izvaja Protokol RS so (2. člen Sklepa o določitvi protokolarnih pravil):

- mednarodni obiski (uradni, delovni in zasebni),

- uradni in delovni obiski doma in v tujini,

- uradni obiski ministrov za zunanje zadeve, uradni in delovni obiski šefov mednarodnih organizacij in specializiranih agencij OZN,

- protokolarni dogodki soproge predsednika RS,

- nastopi, poslovilni in delovni obiski diplomatskih predstavnikov,

- slovesnosti ob vročanju odlikovanj RS,

- podpisi meddržavnih in drugih uradnih listin, pomembnih za državo, predaje akreditivnih pisem,

- slovesnosti ob izrekanju priseg pred predsednikom RS in pred predsednikom DZ RS,

- državni pogrebi, polaganje vencev, 
Zlata Jakša

Vloga protokola v Republiki Sloveniji

- sprejemi, ki jih prirejajo predsednik RS, predsednik DZ RS, predsednik Vlade RS, predsednik Državnega sveta RS in predsednik Ustavnega sodišča RS ter predsednik Vrhovnega sodišča RS,

- sodelovanje pri organizaciji proslav in drugih prireditev državnega pomena.

Naloge Protokola RS so natančneje določene $v$ Navodilih za izvajanje sklepa o določitvi protokolarnih pravil in sklepa o spremembah in dopolnitvah sklepa o določitvi protokolarnih pravil.

\subsection{Sektor za protokol, privilegije in imunitete, diplo- matsko korespondenco ter prevajanje Ministrstva za zunanje zadeve $\mathrm{RS}$}

Sektor za protokol, privilegije in imunitete, diplomatsko korespondenco ter prevajanje Ministrstva za zunanje zadeve (MZZ) opravlja naloge, ki se nanašajo na nudenje pomoči diplomatsko konzularnemu zboru in diplomatskim predstavništvom, mednarodnim organizacijam in njihovim predstavništvom v RS ter konzulatom (tuje misije) ter zagotavlja pogoje za njihovo nemoteno delovanje. Analitično in strokovno obdeluje protokolarna vprašanja, daje pobude in predloge za reševanje vprašanj s svojega delokroga. Vodi potrebne evidence in dokumentacijo. Skrbi za protokolarna darila, celostno podobo MZZ in diplomatskih predstavništev ter konzulatov RS $\vee$ tujini, izdelavo vizitk, vabil in drugih tiskanih dokumentov. Diplomatska predstavništva in konzulate opremlja s simboli slovenske državnosti, sodeluje pri izboru in nabavi opreme $v$ rezidencah in diplomatskih predstavništvih ter konzulatih, uvaja kandidate pred odhodom $v$ tujino $v$ osnove diplomatskega protokola, vedenja in oblačenja. Sektor sestavljajo trije oddelki:

a) Oddelek za privilegije in imunitete ter diplomatsko korespondenco

Oddelek $v$ skladu $z$ določbami mednarodnega in običajnega prava ter notranjega prava RS opravlja naloge, ki se nanašajo na izvajanje diplomatskih privilegijev in imunitet. Skrbi za spoštovanje določb o imunitetah, vsebovanih v Dunajskih konvencijah o diplomatskih in konzularnih odnosih, za zagotavljanje 
vzajemnosti pri izvajanju privilegijev, nudi pomoč pri odpiranju tujih misij, pridobivanju prostorov za tuje misije in po potrebi stanovanj za njihove člane. ${ }^{\mathbf{3}}$

Oddelek vodi evidenco članov tujih misij in njihovih družinskih članov in izdaja diplomatske, konzularne in službene izkaznice. Opravlja posle diplomatsko protokolarnega dopisovanja. ${ }^{4}$ Vodi postopke za izdajo agremanov tujim veleposlanikom in izvaja predajo poverilnih pisem in kopij poverilnih pisem tujih veleposlanikov $\vee \mathrm{RS}^{\mathbf{5}}$ Organizira predstavitvene in poslovilne obiske veleposlanikov, akreditiranih $\vee$ RS. Izdaja diplomatsko listo ${ }^{6}$. Izdeluje poverilna in odpoklicna pisma.

b) Oddelek za ceremonial, organizacijo obiskov in logistiko

Oddelek je odgovoren za protokolarne dogodke MZZ, za delovne obiske tujih zunanjih ministrov ter za druge protokolarne dogodke ${ }^{\mathbf{7}}$, ki jih $\vee$ celoti ali delno organizira MZZ. Spremlja in proučuje mednarodno protokolarno prakso ter ceremonial drugih držav, spremlja vsa vprašanja, ki so vezana na organizacijo delovanja in pogoje dela tujih misij in njihovega osebja. Skrbi za organizacijo mednarodnih konferenc, bilateralnih političnih konzultacij in raznih sprejemov, kosil ter drugih protokolarnih dogodkov.

Opravlja prevoze oseb in materialnih sredstev za potrebe MZZ ter diplomatskih predstavništev in konzulatov RS v tujini. Skrbi za tehnično brezhibnost vozil MZZ ter vodi evidenco vozil na diplomatskih predstavništvih in konzulatih RS v tujini.

\section{c) Prevajalski oddelek}

Opravlja prevode iz tujih jezikov (angleščine, nemščine, francoščine, italijanščine in španščine) v slovenščino in obratno. Področja prevajanja vključujejo diplomatsko korespondenco, pravna besedila, govore, izjave za javnost, poročila, programe, opomnike, stališča, mnenja, dokumente NATO in EU in

3 Naloga oddelka je zagotoviti ustrezne prostorske in stanovanjske pogoje za delovanje posameznih diplomatskih in konzularnih predstavništev ter diplomatskega osebja, kar izhaja iz že omenjene dunajske konvencije (Osolnik, 1998, str. 146).

4 Note, verbalne note, cirkularne note, promemorije, uradna pisma.

5 Služba pripravlja tudi predstavitvena pisma, poverilnice in odpoklicna pisma, patentna pisma za naše konzularne funkcionarje $v$ tujini in eksekvature (dovoljenja za delo za tuje konzule v RS) (Osolnik, 1998, str. 147).

6 Diplomatska lista je redna uradna publikacija vsakega ministrstva za zunanje zadeve, ki vsebuje po določenem univerzalnem sistemu urejen popoln pregled vseh akreditiranih diplomatskih misij in vseh uslužbencev diplomatskega ranga, ki sestavljajo diplomatski zbor $v$ določeni državi (Osolnik, 1998, str. 147).

7 Organizira obiske, sprejeme, kosila in večerje, ki jih prireja zunanji minister ter njegove obiske $v$ tujini - $v$ obeh primerih gre za delovne obiske - in skrbi za ceremonial (Osolnik, 1998, str. 146 - 147). 
drugo. Skrbi za lektoriranje $v$ tujih jezikih, ki ga opravljajo delno zaposleni v prevajalskem oddelku, delno pa tuji govorci - zunanji sodelavci.

Skrbi za pošiljanje besedil zunanjim sodelavcem v lekturo ali prevod (za jezike, ki jih zaposleni ne obvladajo) in usklajevanje rokov. Zagotavlja konsekutivno tolmačenje (angleščina, nemščina, francoščina, italijanščina) in simultano tolmačenje (angleščina, francoščina) ob obiskih tujih predstavnikov in angažiranje tujih tolmačev za obsežnejše konference ali za jezike, ki jih zaposleni v prevajalskem oddelku ne obvladajo. Sodeluje $v$ strokovni skupini vlade za redakcijo prevodov mednarodnih aktov, ki se objavljajo $v$ Uradnem listu RS. Sestavlja glosarje za posamezna področja prevajanja. Opravlja in overja uradne prevode iz slovenščine $v$ angleščino, nemščino, francoščino in italijanščino in obratno.

\section{Praktični vidiki vloge protokola v slovenski protokolarni praksi}

Slovenija se kot manjša država sooča s posebnimi problemi na področju protokola, ki izhajajo predvsem iz različne uvedbe kot tudi različne interpretacije protokolarnih pravil. Eden od pomembnejših problemov je prav gotovo nezgrajenost sistema protokola, kar izhaja iz pomanjkljivega institucionalnega okvira na državni ravni. Posamezni elementi nacionalnega protokolarnega ustroja lahko delujejo še tako dovršeno, toda vse je zaman, če niso povezani v enoten, medsebojno odvisen sistem, ki je vpet v okolje.

Osnovno pomanjkljivost slovenske protokolarne prakse vidim $\vee$ tem, da bi moral biti protokol, kot $v$ večini držav, centralno voden in organiziran $v$ okviru MZZ. Sedanja praksa, da obstajajo ločen diplomatski protokol in več protokolarnih služb in ne povsem urejeno sodelovanje med njimi, z uporabo različnih meril, je posledica dejstva, da do slovenske samostojnosti ni bilo potrebe po specializiranem servisu, namenjenemu za tuja diplomatska in konzularna predstavništva. Ta specifična potreba bo vedno obstajala (privilegiji, imunitete ipd.), vendar je lahko organizirana le kot del enotnega protokola znotraj ministrstva za zunanje zadeve.

Postavlja se vprašanje, kako evidentirati in odpraviti pomanjkljivosti slovenske protokolarne prakse. Naslednji korak, ki bi lahko bil $v$ pomoč pri opredelitvi pomanjkljivosti slovenske protokolarne prakse, bi bil poskus kodifikacije slovenske protokolarne prakse. Treba bi bilo zbrati vse pisane in nenapisane norme slovenske protokolarne prakse, pri čemer bi naleteli na določene pomanjkljivosti zaradi 
razpršenosti pristojnosti. V Sloveniji je protokol decentraliziran, kar vodi do decentraliziranega oblikovanja protokolarne prakse.

Po opravljeni primerjavi bi del, ki odstopa od mednarodnopravno pozitivno urejenih protokolarnih določil, preprosto uskladili, ostaja pa zahtevnejši del, kjer je potrebna uskladitev z mednarodnim običajnim pravom in mednarodno prakso. Uvesti bi morali enoten pristop pri izobraževanju na področju protokola, s koordinacijo bodisi $v$ okviru diplomatske akademije ali $v$ drugih ustreznih oblikah strokovnega izobraževanja ob delu.

Ocenjujem, da bi z uvedbo enotnega protokola odpravili različna merila, do katerih prihaja zlasti pri mednarodnih obiskih. Rezultat zgoraj navedenih pomanjkljivosti je manj pregledna in manj učinkovita zunanja politika.

\section{Zakonski okvir delovanja protokola v RS}

„Protokoli večine držav temeljijo na načelih in predpisih mednarodnega prava, kljub temu pa med državami v protokolarni praksi ni popolne skladnosti«. Poleg tega "se protokol spreminja in prilagaja sodobnim načinom obnašanja", zato "se bodo protokolarna pravila sčasoma dopolnjevala z novimi spoznanji, ki se bodo uveljavila doma in $v$ svetu«. Vsaka država ima namreč tudi nekaj posebnosti, ki so posledica notranjih razmer, sistema vladanja ali pa tradicije (Čačinovič, 1994, str. 76).

Organizacija protokola temelji na določenih pravilih, ki so bila sprejeta z (s):

- Dunajsko konvencijo o diplomatskih odnosih,

- Dunajsko konvencijo o konzularnih odnosih,

- Konvencijo o posebnih misijah,

- Konvencijo o privilegijih in imunitetah Združenih narodov,

- Konvencijo o predstavljanju držav v njihovih odnosih z mednarodnimi organizacijami univerzalnega značaja,

- različnimi dvo- in večstrankarskimi sporazumi.

Temelj za razvoj diplomacije, diplomatskih odnosov in s tem tudi protokola sta nedvomno Dunajska konvencija o diplomatskih odnosih in Dunajska konvencija o 


\section{Zlata Jakša}

\section{Vloga protokola v Republiki Sloveniji}

konzularnih odnosih. Pred tem sta sicer obstajala Dunajski pravilnik ${ }^{\boldsymbol{8}}$ iz leta 1815 ter Aachenski protokol iz leta 1819, vendar sta imela manjši obseg (Simoniti, 1995, str. 20). Zelmanović (1990, str. 245) meni, da sta to dokumenta, ki sta "samo kodificirala prakso in stanje, ki se je oblikovalo skozi tisočletja v odnosih med državami.

\section{Dunajska konvencija o diplomatskih odnosih}

Dunajska konvencija o diplomatskih odnosih kodificira dotedanje mednarodno pravo, obenem pa nakazuje tudi nadaljnji razvoj diplomacije in poudarja pomembnost samega diplomatskega predstavništva kot ustanove. Podrobneje regulira status diplomatskega predstavnika, kot tudi drugih članov diplomatskega predstavništva (Berković, 1997, str. 32 in 33.

Dunajska konvencija o diplomatskih odnosih, ki je bila sprejeta leta 1961, je sestavljena iz naslednjih elementov (Felham, 1993, str. 3):

- predstavljanje države pošiljateljice $v$ državo sprejemnico,

- varovanje interesov države pošiljateljice $v$ državi sprejemnici, $v$ mejah mednarodnega prava,

- pogajanja med delegacijo države pošiljateljice in vlado države sprejemnice,

- delegacija države pošiljateljice je dolžna spremljati dogajanja na vsem ozemlju države v kateri je akreditirana ter o tem obveščati svojo vlado,

- promoviranje prijateljskih odnosov med državo pošiljateljico in državo prejemnico ter razvijanje medsebojnih gospodarskih, kulturnih in znanstvenih odnosov oziroma sodelovanja.

Konvencija je tako prvič uspešno zajela in definirala pojem diplomacije (oziroma vodij diplomatskih misij), opredelila preseans in protokol pri sprejemanju različnih predstavnikov držav. Uredila je tudi vprašanje diplomatskih privilegijev in imunitet (Felham, 1993, str. 16 - 41).

$\checkmark$ konvenciji so predstavljene naloge diplomacije: obveščanje, zastopanje, varstvo, promocija in pogajanje. Spoštovanje konvencije je nujen pogoj, ki ga morajo države upoštevati, da ne pride do diplomatskega nesporazuma ali celo resnejših sporov med državama (Mikolić, 2002, str. 11).

8 S pravilnikom, sprejetim na dunajskem kongresu leta 1815, so bili postavljeni temelji današnjega, sodobnega diplomatskega protokola. $S$ tem in $s$ protokolom na mednarodni konferenci v Aachnu, podpisanim 1818, je bilo določeno hierarhično zaporedje, nazivi diplomatskih predstavnikov, njihove kategorije, stopnje in privilegiji (Zelmanović, 1990, str. 245). 
Konvencija temelji na dveh izhodiščih: na suverenosti držav ${ }^{\boldsymbol{9}}$ in na potrebi po vzdrževanju mednarodne ureditve (»miru in mednarodne varnosti«) z razvijanjem prijateljskih odnosov med narodi. ${ }^{\mathbf{1 0}}$

Sicer pa ni prinesla bistvenih novosti, saj je le pravno uredila tisto, kar se je že uporabljalo v praksi (Simoniti, 1994, str. 13).

Z dunajsko konvencijo je bilo tako urejeno, da se navezava diplomatskih odnosov med dvema državama ne ureja avtomatično, temveč z dogovorom (Zelmanović, 1990, str. 245).

\section{Dunajska konvencija o konzularnih odnosih}

Konvencija je bila sestavljena 1963, veljati pa je začela leta 1967. Po mnenju Simonitija (1994, str. 14) je do zdaj najcelovitejša ureditev te problematike, ne posega $\vee$ že obstoječe sporazume med državami, niti ne omejuje držav, da tudi $\checkmark$ prihodnje ne bi sklepale dvo- ali večstranskih sporazumov.

Cilj Dunajske konvencije o konzularnih odnosih je bil vzpostavitev temeljev za delovanje in spoštovanje konzularnih predstavništev in predstavnikov, ki so nižja oblika diplomatskih predstavništev držav v tujini (Feltham, 1993, str. 56).

Tudi ta konvencija ureja naloge službe diplomatskega protokola, opredeljuje pojme s področja konzularnih odnosov, določa pogoje za vzpostavitev in vodenje konzularnih odnosov, konzularne funkcije ter opravljanje in prenehanje le-teh, prednostni red med konzularnimi predstavniki, olajšave, privilegije in imunitete, ki se nanašajo na konzulat ipd. ${ }^{\mathbf{1 1}}$

\section{Konvencija o posebnih misijah}

Konvencija o posebnih misijah, ki je bila sprejeta leta 1969, opredeljuje pojem specialne misije kot začasne misije, ki predstavlja državo in jo posamezna država pošlje $v$ drugo državo z njenim soglasjem, da bi se pogajala o določenih vprašanjih ali da bi izpolnila določeno nalogo. Poleg tega opredeljuje sestavo in funkcije posebne misije, prostore za njihovo delovanje,

9 Za medsebojno razvrščanje predstavnikov posameznih držav velja abecedni red njihovih imen, zato lahko pride do različnega zaporedja (kadar ne obvelja angleška abeceda, kar je v mednarodnih odnosih navada). Sprejeto je nenapisano vljudnostno pravilo, da država gostiteljica pride na vrsto na koncu spiska, ne glede na zaporedje po abecedi (Zelmanović, 1990, str. 254 in 255).

$10 \mathrm{~S}$ tem je v bistvu opredeljena tudi diplomacija, to je zaščita in predstavitev nacionalnega interesa suverene države in vzdrževanje miru. Na teh dveh načelih temelji tudi celotna zgradba Združenih narodov (Simoniti, 1994, str. 13).

11 Dunajska konvencija o konzularnih odnosih. 
okoliščine, pod katerim prenehajo funkcije posebne misije, ugodnosti in obveznosti misij ipd. ${ }^{\mathbf{1 2}}$

\section{Konvencija o privilegijih in imunitetah Združenih narodov}

Konvencija o privilegijih in imunitetah Združenih narodov je bila sprejeta leta 1946. $\vee$ njej so opredeljene okoliščine, da se zagotovi uživanje privilegijev in imunitet in s tem uresničijo zastavljeni cilji. Zapisane so olajšave za komunikacijo, predstavljene so članice, funkcionarji in strokovnjaki, ki jih organizacija pošlje $\vee$ misijo, za vsakega od teh pa tudi njihove ugodnosti in naloge, ki jih opravljajo. ${ }^{\mathbf{1 3}}$

\section{Dunajska konvencija o predstavljanju držav $\mathbf{v}$ njihovih odnosih $z$ mednarodnimi organizacijami univerzalnega značaja}

Konvencija je bila sprejeta 1975. leta. V njej je opredeljen način predstavljanja držav $v$ mednarodnih odnosih (pri čemer se konvencija sklicuje na že obstoječe konvencije in ustanovno listino Združenih narodov), opredeljene so misije pri mednarodnih odnosih, njihovo vzpostavljanje in sestava, predstavljeni so delegacije pri organih na konferencah, s tem povezane olajšave, odgovornosti in prostori za delovanje subjektov $v$ mednarodni skupnosti.

Poleg zgoraj navedenih mednarodnih konvencij morajo posamezne protokolarne službe upoštevati dodatna zakonska in druga navodila za izvajanje protokolarne dejavnosti. Med drugim Zakon o zunanjih zadevah iz leta 2001, Zakon o grbu, zastavi in himni Republike Slovenije ter o slovenski narodni zastavi iz leta 1994, Navodila za ravnanje ob protokolarnih dogodkih iz leta 1994, Sklep o določitvi protokolarnih pravil v RS iz leta 1994 ter Sklep o spremembah in dopolnitvah sklepa o določitvi protokolarnih pravil iz leta $2002 .{ }^{14}$ Poleg omenjenih dokumentov zlasti za urejanje delovanje Protokola RS velja tudi Pravilnik o notranji organizaciji in sistematizaciji delovnih mest v Protokolu RS ${ }^{\mathbf{1 5}}$; za sektor za protokol, privilegije in imunitete, diplomatsko korespondenco ter prevajanje ministrstva za zunanje zadeve, notranji akt in navodila za opravljanje protokolarnih dejavnosti ter pravilnik o pogojih oprostitev dajatev. ${ }^{\mathbf{1 6}}$

12 Konvencija o posebnih misijah.

13 Konvencija o privilegijih in imunitetah Združenih narodov

14 Dunajska konvencija o predstavljanju držav v njihovih odnosih z mednarodnimi organizacijami univerzalnega značaja.

15 Interni pravilnik Protokol RS.

16 Izdan od Ministrstva za finance. 


\section{Predlog organiziranosti enotnega protokola RS}

$\checkmark$ Sloveniji je protokol decentraliziran, kar pomeni več koordinacije in več komunikacije in zveča možnost napak. Zavzemam se za čim bolj centralizirano ureditev, po mojem mnenju ta bistveno izboljša učinkovitost, omogoča boljši pretok informacij zaradi »bližine« organu oziroma nosilcu oblasti. Zavzemam se namreč za čim večjo kakovost, tudi ob povečanem obsegu in razlikah $v$ vrsti dela, ki smo mu priča $\vee$ zadnjih nekaj letih; to pa je mogoče doseči po mojem mnenju le z najboljšo, močno koordinacijo dela, ki jo izvaja ena, osrednja služba, ki skrbi za izvajanje vse protokolarne prakse na najvišji državni ravni.

Ocenjujem, da bi z uvedbo enotnega protokola odpravili različna merila, do katerih prihaja zlasti pri mednarodnih obiskih. Glede na to, da je ministrstvo za zunanje zadeve vsake države glavni kanal izmenjevanja informacij, lahko $v$ tem okviru razmišljanja razumemo ključno vlogo zunanjega ministrstva tudi pri izvajanju dela protokolarne prakse.

Po pridobljenih izkušnjah si zamišljam glavno protokolarno službo pri zunanjem ministrstvu. Protokolarna služba bi skrbela za organizacijo obiskov predsednika države, predsednika vlade, zunanjega ministra, za akreditirane veleposlanike, konzule in predstavnike držav pri različnih mednarodnih organizacijah. Protokolarna služba bi organizirala obiske nosilcev protokolarnih pravic $v$ tujini, obiske tujih državnikov in gostov zunanjega ministrstva in mednarodne konference, ki jih organizira zunanje ministrstvo. Sektor bi sestavljali štiri oddelki:

- Oddelek za obiske predsednikov držav, predsednikov vlad, zunanjih ministrov. Uradni in delovni obiski doma in $v$ tujini.

- Oddelek za diplomatske in konzularne misije, mednarodnih organizacij, ceremonial

- Oddelek za mednarodne konference, multilateralna srečanja

- Oddelek za splošne zadeve, diplomatske izkaznice, darila, prevajanje.

Priprava protokolarnih dogodkov $\vee$ posamezni državi je timsko delo več državnih instituciji, kar dokazuje tudi sodelovanje protokolarnih služb z drugimi državnimi organi. Večja protokolarna služba bi bila tudi v okviru ministrstva za notranje zadeve (MNZ). Protokolarna služba pri MNZ bi bila odgovorna za varovanje oseb s protokolarnimi pravicami, domače dogodke, kot so obeleževanje državnih praznikov in državniški pogrebi. Odgovorni bi bili tudi za primerno uporabo državnih simbolov (grba, zastave in himne). 


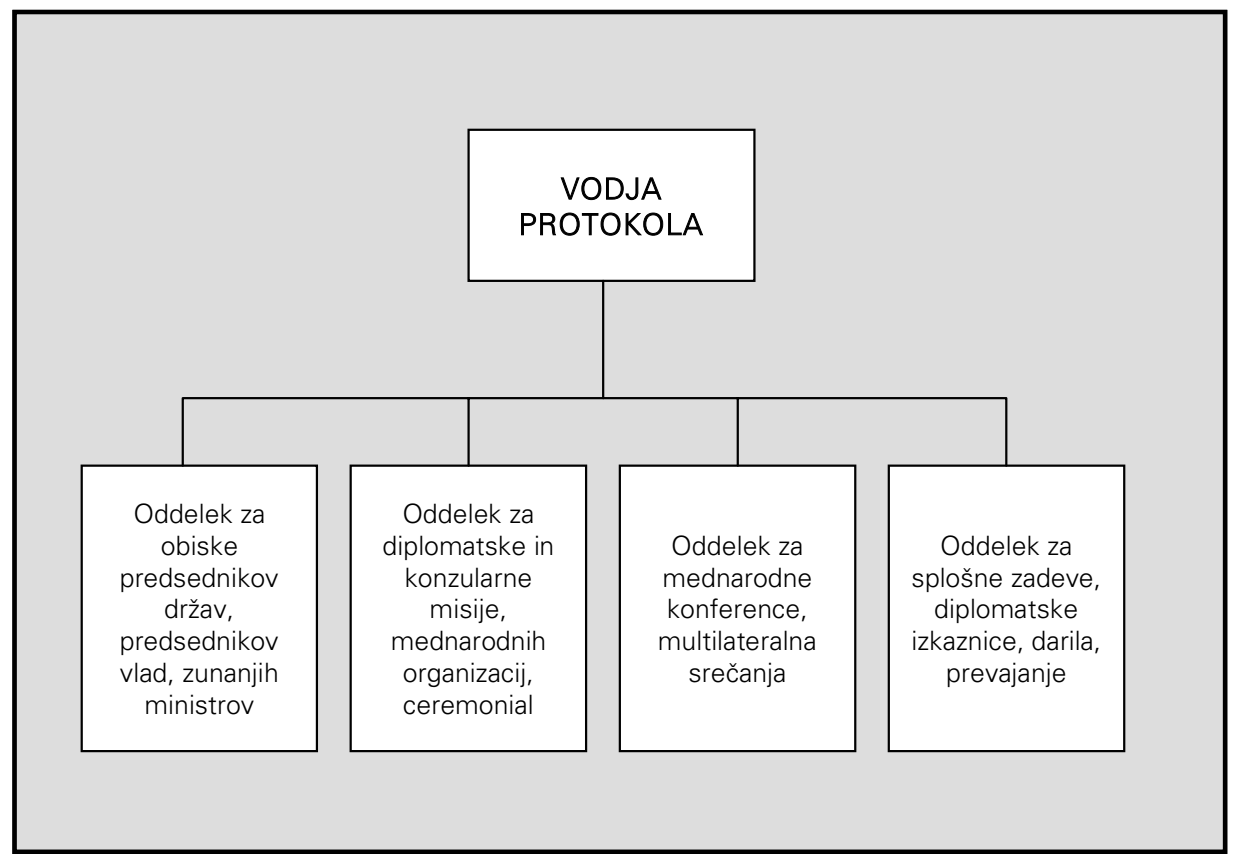

Pomembno je tudi sodelovanje z državnimi centri za informiranje (v Republiki Sloveniji vladni urad za informiranje med drugim skrbi tudi za novinarje, ki poročajo o posameznih protokolarnih dogodkih), državnimi servisi za (avtomobilske in letalske) prevoze, različnimi servisi za protokolarne storitve, ki upravljajo protokolarne objekte, vse bolj pomembno pa je tudi sodelovanje s podjetji, pomembnimi za zunanjo politiko.

\section{Zaključek}

Protokol je pomemben za uresničevanje zunanjepolitičnih ciljev države, saj ustrezno mesto in vloga protokola in prilagoditev posameznim državam vodijo $\mathrm{k}$ učinkovitejšemu delovanju, ugledu, promociji in spoštovanju držav, izražajo vsebino in "osebno izkaznico" države. Lastne, osebne izkušnje države so izraz njenih nacionalnih posebnosti in posledično pomagajo pri uresničevanju zunanjepolitičnih ciljev države.

Diplomacija se ravna po mednarodno uveljavljenih pravilih diplomatskega protokola, ki izhajajo iz zgodovinskih tradicij in običajev, načel mednarodnega prava in diplomatske prakse. Razvila so se z namenom, da se stiki predstavnikov držav olajšujejo in odvijajo na skladen in vnaprej določen poenoten način. Cilj teh 
pravil je zaščita dostojanstva, spoštovanja in ugleda vsake države kakor tudi njihovih najvišjih državnih in diplomatskih predstavnikov, olajšanje medsebojne komunikacije in hkrati s prijetno družabnostjo vzpostavitev ozračja medsebojnega zaupanja. Za diplomacijo in protokol je mogoče reči, da sta nastala $v$ »funkciji zgodovinske situacije«.

Protokolarna pravila države upoštevajo ne glede na njihovo sorazmerno velikost. Protokol kot takšen nastopa kot vezni člen, ki relativizira težo moči držav in hkrati deluje $v$ funkciji preseganja kulturnih razlik, kajti na protokolarni ravni so vse države relativno enake.

Zgoraj navedene trditve lahko pripišemo dejstvu, da so $v$ mednarodnem diplomatskem pravu države pravno izenačene, zato lahko protokol štejemo kot vezni člen, ki blaži razlike med močjo držav. Pri tem so lahko pravila protokola pomemben blažilec $\vee$ primerih, ko se odnosi med dvema državama poslabšajo ali celo padejo na zelo nizko raven, saj nudijo diplomatom koristno oporo, ki preprečuje, da bi bila dejavnost diplomatskih misij še bolj prizadeta. To je še posebej ugodno za manjše države, ki dobijo skozi izbiro protokolarnih postopkov in ustrezno protokolarno obravnavo možnost enakovredno odigrati svojo vlogo v mednarodnem okolju.

Protokolarna pravila in mednarodnopravno urejanje so nastala zaradi zahteve po spoštovanju ugleda diplomatskih predstavnikov, ki so ga razumeli kot ugled države s ciljem zmanjševanja medkulturnih razlik med državami. Manjše države morajo protokolarno enako ravnati kot velike države, velike države pa enako kot manjše, saj je protokol področje, kjer ni razlik $v$ tehtanju moči. Ob tem pa moramo pri analizi upoštevati dejstvo, da okolje nudi manjšim državam drugačne omejitve in priložnosti kot pa velikim državam. Zato si morda velike država lahko "privoščijo manjše spodrsljaje», manjše pa ne, zlasti če težijo za tem, da bi bile dobro organizirane in mednarodno uveljavljene.

Protokol je eden izmed "mehkih « dejavnikov moči, ki je za manjše države pomembnejši kot za velike države. Slovenija bi morala biti kot manjša država relativno skromna in hkrati pokazati svojo samobitnost in ne mentalitete velesile. 


\section{Zlata Jakša}

\section{Vloga protokola v Republiki Sloveniji}

Zlata Jakše je leta 2007 zaključila specialistični študij študijskega programa Javna uprava na Fakulteti za upravo. Od leta 1995 je zaposlena na Ministrstvu za zunanje zadeve. Leta 2002 je bila napotena na veleposlaništvo v Den Haag. Po vrnitvi v Slovenijo je bila razporejena $v$ Sektor za protokol, privilegije, imunitete, diplomatsko korespondenco, prevajanje $v$ oddelek za ceremonial, organizacijo obiskov in logistiko.

\section{Literatura in viri}

- $\quad$ Benedetti, K. (2003): Izboljšanje kakovosti na področju državnega protokola http://mju.gov.si/fileadmin/mju.gov.si/pageuploada/mju_dokumenti/pdf/ksenija20 benedetti.pdf (13. 6. 2005).

- $\quad$ Dunajska konvencija o diplomatskih odnosih (Uradni list SFRJ, Dodatek 2/64).

- $\quad$ Dunajska konvencija o konzularnih odnosih (Uradni list SFRJ, Dodatek 5/66).

- Dunajska konvencija o predstavljanju držav v njihovih odnosih z mednarodnimi organizacijami univerzalnega značaja (Uradni list SFRJ, st. 3/77).

- Internet 1: Diplomatski protokol http://www.gov.si/mzz/ministrsty/diplomatsk prot.html (4. 7. 2005)

- Kodeks v Protokolu Republike Slovenije (2005). Interno gradivo, Protokol RS.

- Konvencija o posebnih misijah (Uradni list SFRJ, st. 19/75).

- Konvencija o privilegijih in imunitetah Združenih narodov (Uradni list FLRJ, st. 20/50).

- Navodila za izvajanje sklepa o določitvi protokolarnih pravil in sklepa o spremembah in dopolnitvah sklepa o določitvi protokolarnih pravil (Uradni list, st. 95/2002).

- Navodila za ravnanje ob protokolarnih dogodkih (1994). Protokol RS.

- Osnovna protokolarna pravila (2003). Protokol RS. Interno gradivo.

- $\quad$ Sklep o določitvi protokolarnih pravil v RS (Uradni list RS, st. 36/94).

- $\quad$ Sklep o spremembah in dopolnitvah sklepa o določitvi protokolarnih pravil (Uradni list RS, st. 95/02).

- Slovar tujk (2002). Državna založba Slovenije. Ljubljana.

- Zakon o zunanjih zadevah (Uradni list, st. 45/2001). 


\section{THE ROLE OF PROTOCOL IN THE REPUBLIC OF SLOVENIA}

Protocol is a special notion both in international and human relations. It comprises the rules of behaviour in different situations and on different occasions ranging from basic manners that apply in every-day private life to complex rules or even internationally accepted standards regulating the relations between countries and their representatives.

Every organisation must respect certain rules in order to be successful and to prevent complete chaos. Interstate relations must develop according to generally accepted rules and customs and in an organised way and a plan prepared in advance.

Protocol has been part of everyday life of many peoples for thousands of years, from the very moment when societies were forced to regulate their mutual relations through representatives. Such representatives had an important role, particularly in smaller, more democratic societies, where equality prevailed. On the other hand, great powers achieved their goals by force and only rarely through negotiations; nevertheless, they contributed to international law.

The diplomatic protocol performs standard protocol tasks. It pays great attention to ceremonial which is part of the diplomatic protocol. Slovenia's ceremonial complies with both Slovenian customs and international practice. It frequently shows the nature of relations between countries. Certain forms of politeness and courteous behaviour ensure that the relations between statesmen and diplomatic representatives are built up on the basis of mutual respect, credibility and trust. In addition to consistency as far as protocol is concerned, a personal approach is essential. I believe that our protocol personnel are not too stiff and formal, but very hospitable and sociable. They always do their best to ensure that their guests feel well and spend a pleasant time in Slovenia. We have gained wide experience in organising visits; we can say that our guests from abroad appreciate the personal touch and kindness, particularly those from the West, since they do not have a feeling that they are just numbers.

The Protocol of the Republic of Slovenia performs protocol tasks for the President of the RS, the President of the National Assembly, the Prime Minister, the President of the National Council, the President of the Constitutional 
Court, the President of the Supreme Court, the Human Rights Ombudsman, the President of the Court of Auditors, and the Minister of Foreign Affairs.

Protocol events organised and handled by the Protocol of the Republic of Slovenia include:

- International visits (official, working and private ones);

- Official and working visits at home and abroad;

- Official visits by ministers of foreign affairs, official and working visits of heads of international organisations and UN specialised agencies;

- Protocol events of the spouse of the President of the Republic of Slovenia;

- Introductory visits, farewell visits and working visits of diplomatic representatives;

- Ceremonies on awarding state decorations;

- The signing of inter-state and other official documents of importance to the state;

- Presentation of credentials;

- Solemn oaths before the President of the Republic of Slovenia and the President of the National Assembly;

- State funerals and the laying of wreaths;

- Receptions hosted by the President of the Republic, the Prime Minister, the President of the National Council, the President of the Constitutional Court, and the President of the Supreme Court;

- Organisation of celebrations and other events of state importance.

The tasks of the Protocol of the Republic of Slovenia are specified in the Instructions on the implementation of the Decision on setting protocol rules and the Decision amending the Decision on setting protocol rules (2002).

"The protocol of most of the states is based on the principles and rules of international law; nevertheless, there is no uniform protocol practice among states". In addition, "protocol is changing and adapting itself to modern behaviour", therefore "protocol rules will eventually be supplemented by newly acquired knowledge that will gain ground at home and 
abroad". Every country has certain specifics resulting from the domestic situation, the system of governance, or tradition (Čačinovič, 1994, p. 76).

The organisation of protocol is based on certain rules enshrined in:

- The Vienna Convention on Diplomatic Relations;

- The Vienna Convention on Consular Relations;

- The Convention on Special Missions;

- The Convention on the Privileges and Immunities of the United Nations;

- The Convention on Representing States in their Relations with International Organisations of a Universal Character;

- Different bilateral and multilateral agreements".

The beginnings of Slovenian diplomacy saw certain difficulties as regards protocol because the Republic of Slovenia was a new state with no protocol and tradition which would facilitate the work of the state authorities. Therefore, everything had to be developed from scratch, rules had to be set and personnel trained accordingly. This is a demanding task which has not yet been completed.

Slovenia as a small country is facing specific problems in the field of protocol resulting from differences in the implementation and interpretation of protocol rules. One of the problems raised is a deficient protocol system as a result of a deficient institutional framework at the state level. Individual elements of the national protocol system may function perfectly, but to no avail, if they are not part of a uniform interdependent system fitting into the environment.

In my opinion, the fundamental deficiency of Slovenia's protocol practice lies in the fact that the protocol service is not - like in most other countries - directed centrally and organised within the Ministry of Foreign Affairs of the Republic of Slovenia. The present practice - a separate Diplomatic Protocol and several protocol services, which do not always cooperate impeccably - arises from the fact that until Slovenia's independence there had been no need for a specialised service intended for foreign diplomatic representations and consulates. The need for this specific service will always exist (privileges, immunities, etc.); it may however be organised only as part of a uniform protocol service within the Ministry of Foreign Affairs. 
Zlata Jakša

Vloga protokola v Republiki Sloveniji

The question remains as to how to identify and eliminate the deficiencies of Slovenia's protocol practice. The following steps could be of assistance:

- An attempt at codifying Slovenia's protocol practice; All written and non-written norms of the Slovenian protocol practice should be gathered, whereby certain deficiencies would be encountered due to the dispersion of powers. In Slovenia the protocol service is decentralised which leads to a decentralised formulation of the protocol practice.

- Comparison with the international practice and the practice of some carefully selected comparable states. Following such a comparison, the part deviating from protocol provisions under international law should be brought into line first. A more demanding part of adjustment would however remain, i.e. harmonisation with international customary law and international practice.

- A uniform approach to education and training in the field of protocol. Such education and training should be coordinated within a diplomatic academy or through some other appropriate form of off-the-job training.

In my opinion, the introduction of a uniform protocol service would eliminate the differences in criteria which become evident during international visits. The overall consequence of the above-mentioned deficiencies is a less transparent and efficient foreign policy. 